Mullinix and Linder were both arrested, and held under bail to answer to the indictment at the next term of the court. At the next term of the court they both appeared, and Linder went to trial, "which resulted in his conviction, and a sentence of a fine and ten days imprisonment in the penitentiary." The trial of Mullinix, the Sheriff, was continned until the next term of the court ; and he was required to enter into a recognizance (without security) for his appearance, which he refused to do, and the court ordered him to be committed to prison.

As soon as these transactions were made known to Gov. Chambers, he pardoned Linder and remitted his fine, and also pardoned Mullinix for the offence with which he stood committed, and ordered him to be discharged from prison.

After the arrest of Mullinix and Linder, the county of Adair was divided, and the territory adjoining Davis county was embraced within the limits of Schuyler county.

[Concluded in next number.]

\title{
THE ORIGIN ANI) INTERPRETATION OF THE NAMES OF THE RIVERS AND STREAMS OF CLAYTON COUNTY.
}

BY ELIPHALET PRICE.

[Continued from page 711.]

We now approach "Plumb Creek," the last and the most southern of all the streams flowing into the Mississippi from the County of Clayton. This stream received its name from John Plumb, who, in 1836, purchased out the claimants to an extensive tract of timber land, through which it flows, and commenced the building of a saw-mill, which he soon after abandoned, owing to an insufficiency of water in the stream. We had some aequaintance with Mr. Plumb, and as we knew him to be the originator of the great idea of a Pacific Railroad, we will venture, as an expression of respect for his memory, to briefly speak of him here in connection with that great idea. Mr. Plumb was born in Wales, in the kingdom 23 
of Great Britain, and emigrated to this country in 1821, at the age of twelve years. In the spring of 1835 he became a resident of Dubuque, and in 1837 conceived the idea of a railroad from the Lakes to the Pacific ocean, and immediately commenced advocating his project through the medium of the New York and Boston press. Being in the enjoyment of a pecuniary competency, and a ready writer, possessing a high order of educational attainment, together with a fluent command of language, which enabied him to present from the public rostrum this great national theme with a display of argumentative power, convincing; pleasing and captivating, he, in the summer of 1838 , convened a large public meeting at Dubuque, where, for the first time in public, he submitted his project of a railroad from the Lakes to the Pacific ocean, urging upon the people of the West the importance of securing from the National Government, in aid of this work, a grant of land extending from the Lakes to the Pacitic ocean, before the public domain was otherwise appropriated by the Government. Soon after this meeting Mr. Plumb commenced lecturing in different parts of the Union upon this subject. In the cities of Boston, New York, Philadelphia, Baltimore, Washington and throughout the West, he drew around him the mind and capital of the country, and while for a time it stood timidly aloof, startled by the gigantic character of the work, gradually it drew nearer to listen to the feasibility of his plans and the great national benefits that would result from its consummation. The public press throughout the Union began to drift cautiously into the channel of his thoughts, when the discovery of the gold fields of California almost immediately cansed his great project to burst upon the national mind as a reality to be consummated at the earliest moment. In 1849 he visited California by the overland route, leisurely viewing the country by way of the South Pass. Upon reaching the gold mines, he again resumed lecturing and writing upon this subject, giving to it the largest portion of his time, during a residence there of four year's. In 1855 he returned to Dubuque, disheartened and discouraged. He had ex- 
hamsted a liberal fortune in his efforts to impress the national mind with the importance of taking speedy action upon this great project; pecuniary embarrassments began to loom up and weave around him their enthralments, when his mind, yielding to the throes of dispondency, reeled from its once brilliant pathway and rnle-sinking to the gloomy haunts of despair, with his own hand he terminated his career among men, at the city of Dubuque, in May, 1857. Such is our remembrance of John Plumb, one of Iowa's earliest pioneers, and while his name is fast passing away from a national remembrance, it may live in the babbling murmurs of the little stream we have recorded, as long as its rippling waters shall course their way along the windings of its rocky bed, canopied in its forest solitude by the drooping foliage of the Elm, the Linden and the Mountain Ash.

Haring given the origin and interpretation of the names of those streams which empty into the Mississippi along the eastern boundary of the county, we now approach the tributaries of Turkey river, which are more numerous and which permeate a larger area of the county. About one mile from the mouth of Turkey river, a small but beautiful stream empties into it, after winding its way for the distance of four miles among the rugged timiered hills that recede away towards the South. Upon reaching the river bottom, its waters become silent, deep and of a bluish color, and in winding its clear, cold and sluggish course through the river bottom, it forms almost a circle, from which circumstance it is known by the name of "Blue Belt," having received this name from Col. William W. Wayman, who was the first white man that settled in the county, having erected a cabin near the mouth of this stream in the fall of 1833 . Col. Wayman, who died a number of years since, we shall refer to more fully when we reach the stream that preserves his name.

About a mile further up the river, there is a small stream also flowing from the south and known by the name of "Joe's Branch." This stream received its name from Joseph B. Quigley, who in 1836 made a claim location upon the river 
bottom through which it winds. Mr. Quigley is still a resident of the county, being numbered among the most prosperous and affluent farmers in Highland township, on the western boundary of the county. We have never met with a person whose mechanical genius was more versatile and variable than his. During his early years as a resident of the county, he was a millwright, a tailor, cabinet-maker, milliner, shoemaker, carpenter, cooper, blacksmith, boat builder, weaver, wagon maker, and we have seen him cut and make a calico dress for a woman. In all these varied arts he was recognized as a master workman. Soon after he married and became a father, he undertook to invent a new and more convenient plan for diapering a child, and failed; since then his mind has been almost wholly given to agricultural and horticultural pursuits. Like the few remaining early settlers of the county, time has touched his locks, and they are fast whitening under its influence.

A short distance farther up the river, "Little Turkey" empties its waters into the parent stream, after flowing from the south through a timbered country for the distance of eight miles-its source being in the County of Delaware. The towns of Millville and Jefferson are situated upon this stream, together with several flour and saw mills. It received its name from Arthur Rowen, who erected a saw-mill at Millville in 1835 , being the first mill built in the county. Mr. Rowen, while exploring the country in search of a mill site, came upon this stream at a time when its banks were overflowed by rains, giving it a width and impetuosity almost equal to the parent stream; from which circumstance he called it " Cittle Turkey River."

A mile farther up the river, a small stream empties into it from the south known as "Redman's Branch." This stream took its name from Henry Redman, who settled upon the river bottom near its mouth in 1834 . He was the flrst white man who brought his wife and family into the county; being about forty years of age, he was the oldest resident of the county at that time. His eabin door stood always open to 
the unfortunate and the stranger, who were greeted with a kindly welcome and liberal hospitality. He was a thin wiry man, of great muscular powers, and was regarded during his earlier years as the best tighting man in the lead mines. The fingers of his hands were crooked by mastication, while his arms, face and shoulders showed many scars made by the lacerating teeth of his opponents. In later years he became an active and zealous member of the Methodist Church, and often at class meetings, while recounting the scenes of his early life with expressions of sorrow and regret, he would straighten up his bent form, shake his silvery locks, and conclude by saying: "But, brothers and sisters, thank God I was never whipped." The day before he died, at his request, many of the early settlers convened at his residence. It was a Sabbath morn in early autumn; the crimson leaf of the maple was fast eddying its way to the ground, and rustled in the forest pathway that led up the little eminence to his home that overlooked the waters of Turkey river; Doctor Griffith, one of the number, offered up an excellent and appropriate prayer; a psalm was sung; the scenes of other days talked over. At length the parting hour came, when each approached his bed, took him by the hand and bid him farewell, and as each turned away from the scene, tears could be seen coursing along the pathways that time had furrowed upon the cheeks of Clayton's pioneers.

CDon the north side of the river, a short distance above the last named stream, may be seen a small rivulet known as "Park's Branch." This stream takes its name from Thomas P. Park, who settled here in 1838. Capt. Park was one of the early Sheriffs of the county - a man of fine personal appearance and gentlemanly address; he was a kind hearted, benevolent and hospitable man, officiating occasionally as a preacher of the Baptist persuasion. In 1840, we saw him at Coulie-de-Sue, on the Mississippi, in an unfinished building, which was being erected by Messrs. Jones \& Bass, win the entire funds of a faro bank, which was being operated under the financial management of a professional banker from $\mathrm{Ga}$ - 
lena, and on the following Sabbath we heard him deliver an able and excellent sermon upon the vice and evils of gambling, to a congregation of his neighbors convened at the honse of Henry Redman, on Turkey river, distant some thirty miles from the scene of the bank disaster. He was a man of fluent address and varied attainments, and was much respected by his neighbors as well as greeted with kindly feelings by all who knew him. He died a number of years since upon the stream that preserves his name.

About two miles further np the river, a small stream empties into it from the south, known as the "Henderson Branch." This stream takes its name from Cyrus Henderson, who, in 1836, erected a blacksmith shop upon the river bottom near its mouth. There being but a few settlers in the neighborhood to give him employment, he soon abandoned the place. He was a boy when he started this enterprise, but now his locks have whitened, and the ring of his anvil may still be heard among the echoes of the high hills in Millville township, that overlook the sequestered valiey and the winding stream that murmurs by his home.

A short distance above this stream, "Pecle's Branch" unites its waters with the Turkey, after flowing in a northerly direction a distance of eight miles, through high mountainous hills covered with a dense and heary growth of timber. This stream takes its name from Dudley Peck, who located upon the river bottom near its month in 1835 . He was a young man from Western New York, and as a hunter had no superior in the country. Up to the period of his death, he persistently refused to hunt with a gun having a percussion lock, always using the old fashioned flint-lock rifle, whose superior qualities he would often defend by referring to the achievements of Cooper's heroes, Hawk-eye, Leather-stocking and the Trapper. No argument could subdue his aversion to a - shot-gun; on one occasion, while dining with him at his bachelor cabin, a person from Cassville came in with a doublebarrel shot-gun, which he stood up against the chimney jam, Peck immediately arose from the table and observed, 
"Stranger, if you have no objections I will place your gun outside of my cabin;" which he did without waiting for a reply, and then invited the stranger to "sit up and eat." Towards the close of his days, he was afflicted with a painful, lingering disease, which he knew was to terminate his life, and on one occasion, while brooding over the certainty of his never again being able to hunt, he expressed to us with much feeling his regret at never having killed a panther; he seemed unwilling to die before he had added this achievement to the many victories he had obtained over the animals of the forest. He was our earliest, nearest neighbor, and many have been the pleasant wintry evenings that we liave sat by the huge log fire of his cabin and listened to the thrilling details of his hunting adventures.

Directly opposite Peck's Branch, flowing from the north, is a small stream known as "Price's Branch." This stream takes its name from the writer of this article, who settled here in 1835, and who afterwards located at the source of the stream upon the highland prairie. As there is nothing in the history of this person that is not common to other men, we pass on to the "Carlin Creek," distant about one mile furtlier up the river. This stream, flowing from the south, takes its name from William Carlin, who located here in 1836, and soon after abandoned the place. Mr. Carlin was born and raised upon the frontier, and was a hunter by profession; he could neither read nor write, and was a nephew of Gov. Carlin, of Illinois. He died a number of years since.

[To be Continuéd.]

\section{JOHN BROWN AMONG THE PEDEE QUAKERS.}

[Continued from page 719.]

CHAPTER III.

Shortly before Brown's last departure from Pedee, he effected a sale of such plunder as had been necessarily employed in the transportation of negroes and arms from Missouri and Kansas, such as mules, wagons, stoves and cooking utensils, and tents and other camp equipage, by which he realized a 
Copyright of Annals of Iowa is the property of State of Iowa, by \& through the State Historical Society of Iowa and its content may not be copied or emailed to multiple sites or posted to a listserv without the copyright holder's express written permission. However, users may print, download, or email articles for individual use. 